ИЗВЕСТИЯ АКАДЕМИИ НАУК ЭСТОНСКОП ССР. ТОМ 30 Химия. 1981, № 3

\title{
THE DETERMINATION OF DIFFERENT PHASES OF PANCREATITIS BY ISOELECTRIC FOCUSING
}

The diseases of the pancreas play an important role in the pathology of the gastro-intestinal tract. However, a lot of problems arising in connection with the investigation of this pathology cannot be solved without using immunological methods. Both experimental and clinical investigations have demonstrated that antigens of the pancreas are capable of inducing immune response. As the antigens of pancreas are distinctively specific, in evaluating suitable immunological reactions in humans it is advisable to proceed from the antigenic characteristics of human pancreas. Thus, the antigenic characteristics of subcellural fractions of the pancreas is of primary importance in clinical investigations at diagnosing pancreatitis of different phases.

In our earlier works on the immunology of pancreatitis, we used qualitative and semiquantitative methods to determine circulating antibodies in the blood serum of patients in case of pancreatitis and cancer of pancreas $\left[{ }^{1}\right]$. The level of circulating antibodies in the blood of patients with an acute and chronic stage of pancreatitis was also studied by the method of affinity chromatography, using columns with a «Lahema» synthetic hydrogel Spheron P-1000 bound to a tissue extract of pancreas with 2-amino-4,6-dichlortriazine [ $\left.{ }^{2}\right]$. The above-mentioned methods are rather time-consuming and not precise, and therefore we decided to use a new method of isoelectric focusing in polyacrylamide gel plates with carrier ampholytes, which is considered to be more sensitive, specific and more rapid than other methods, and is used in many sciences, especially in clinical applications and in immunology.

The aim of this work is to determine different phases of pancreatitis by using isoelectric focusing.

\section{Material and methods}

Equipment: LKB 2117 Multiphor set for isoelectric focusing in polyacrylamide gel.

Chemicals: Carrier ampholytes in the $\mathrm{pH}$ range 5.2-9.0, synthesized according to Murel $\left[^{3}\right]$; acrylamide, N,N-methylene-bisacrylamide, both recrystallized, are from «Reanal» (Hungary); N,N,N,N-tetramethylethylenediamine (TEMED) from «Reanal» (Hungary); ammonium persulphate analytical grade from «Reanal»; glycerol, $87 \%$, analytical grade, from the USSR; coomassie brilliant blue R-250.

Fixing solution: $7.3 \mathrm{~g}$ sulphosalicylic acid and $57.5 \mathrm{~g}$ trichloroacetic acid in $500 \mathrm{ml}$ of distilled water. 
Fig. 1. $\mathrm{pH}$ gradient of a polyacrylamide plate following isoelectric focusing for $3 \mathrm{~h}$.

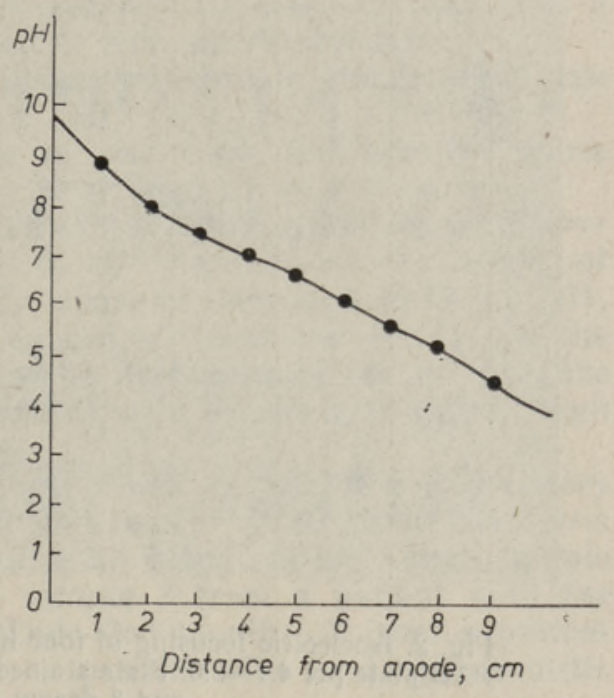

Staining solution: $0.460 \mathrm{~g}$ coomassie brilliant blue $\mathrm{R}-250$ in $400 \mathrm{ml}$ of destaining solution.

Destaining solution: $500 \mathrm{ml}$ ethanol and $160 \mathrm{ml}$ acetic acid in 21 of distilled water.

Preserving solution: $50 \mathrm{ml}$ glycerol in $500 \mathrm{ml}$ of destaining solution.

\section{Formation of the gel}

Gel was made of acrylamide with methylene-bisacrylamide as a crosslinker containing $3.9 \%(\mathrm{w} / \mathrm{v})$ acrylamide, N,N-methylene bisacrylamide (bis) $0.13 \%(\mathrm{w} / \mathrm{v})$, to which ampholine in the $\mathrm{pH}$ range $4.2-9.5-4 \mathrm{ml}$, glycerol $5.95 \mathrm{ml}$ and TEMED $0.1 \mathrm{ml}$ was added and was made up to $60 \mathrm{ml}$ with distilled water. The mixture was degassed for 4 min under vacuum, thereafter ammonium persulphate $0.004 \mathrm{~g}$ per $2 \mathrm{ml}$ was added. The solution was immediately pipetted into the gel mold for polymerization $\left[{ }^{4}\right]$.

\section{Sample application and electrophoretic run}

Samples of human blood serum $(10 \mu \mathrm{l})$ were applied to a cathodic end of the polyacrylamide gel slab on filter paper squares. Isoelectric focusing was performed on an LKB-2117 Multiphor System at $10 \mathrm{~W}$, 1200 V maximum (using an LKB-2103 Power Supply) with cooling at $4^{\circ} \mathrm{C}$. The anode electrolyte was $0.1 \mathrm{M}$ phosphoric acid and the cathodic electrolyte $0.1 \mathrm{M} \mathrm{NaOH}$. After focusing for $3.5 \mathrm{~h}$ the $\mathrm{pH}$ gradient in the polyacrylamide gel slab was measured by a surface electrode (Fig.1).

\section{The treatment of polyacrylamide gel after focusing}

The focused gel was immediately placed into a fixing solution for $1 \mathrm{~h}$. The gel was removed from the glass with a spatula and then placed into the destaining solution overnight at room temperature. The gel was preserved between two sheets of cellophane, 


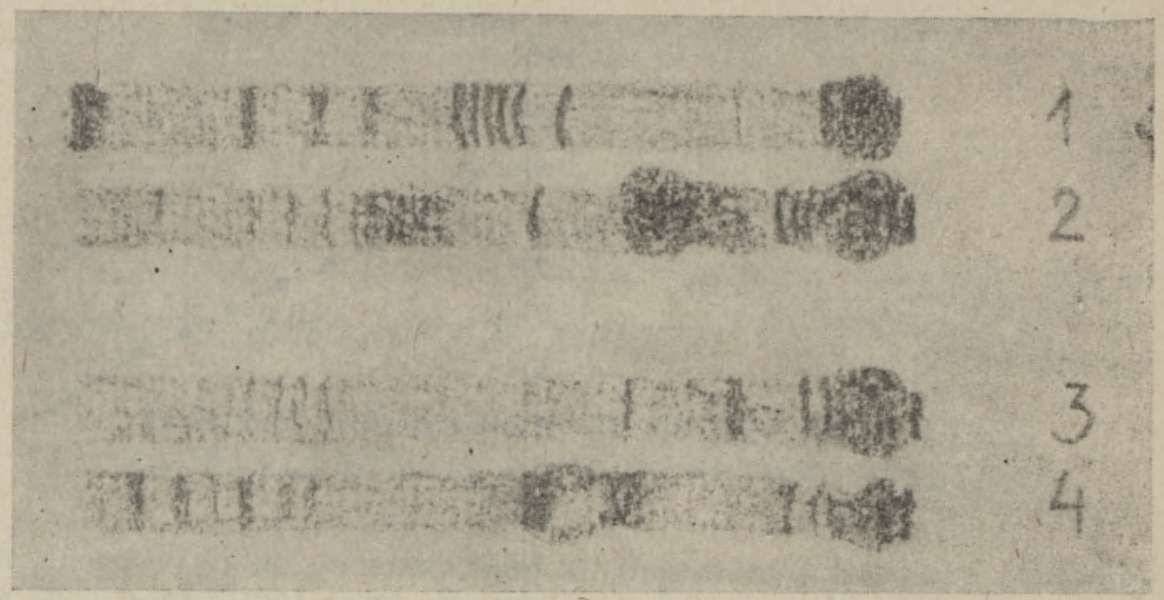

Fig. 2. Isoelectric focusing of four human serum samples on an ampholine PAG plate $\mathrm{pH} 4.1-9.0$. Plate stained with coomassie brilliant blue. (Figs 2 and 3 drawn from the plate.)

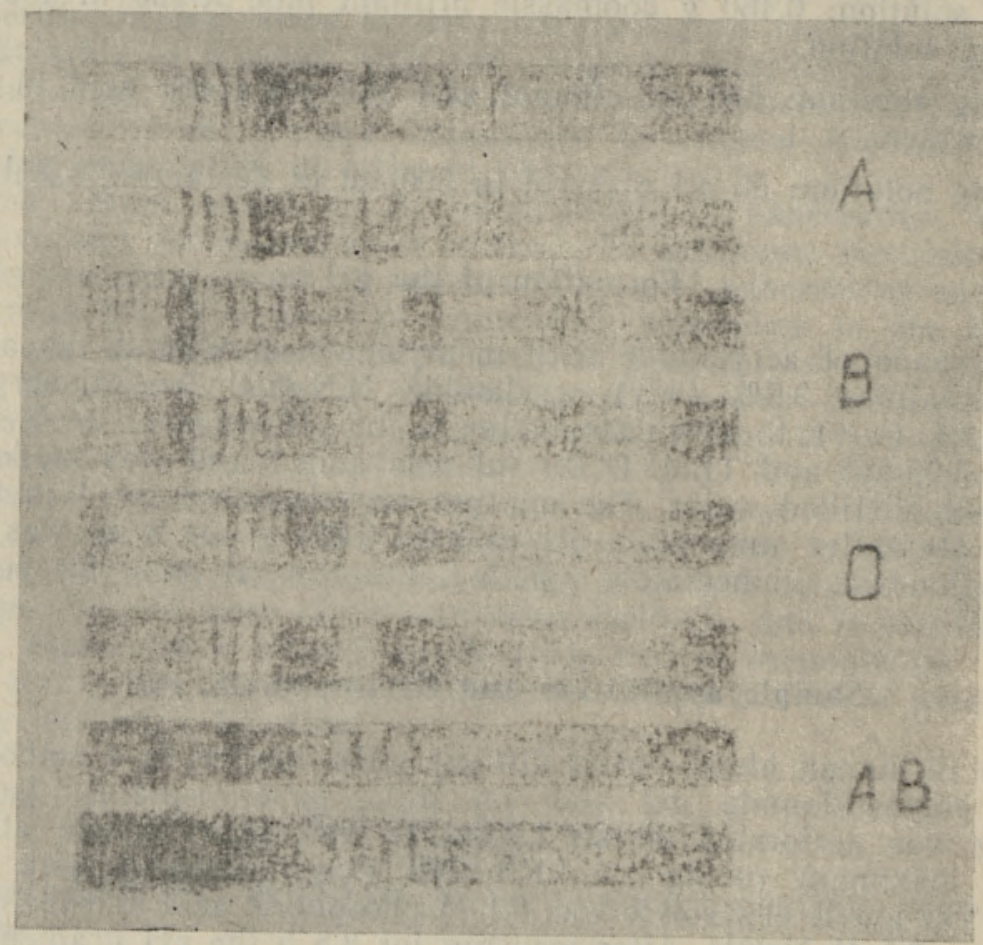

Fig. 3. Isoelectric focusing of different blood groups on an ampholine PAG plate, $\mathrm{pH} 4.1-9.0$. Plate stained with coomassie brilliant blue.

\section{Results}

Persons suffering from different phases of pancreatitis and cancer of pancreas have an extremely high level of different immunoglobulins in 
their blood serum. The patients with pancreatitis were divided into 2 groups on the basis of the clinical picture and laboratory data:

1. Acute pancreatitis or acute conditions of chronic pancreatitis (an active phase of the disease).

2. Chronic pancreatitis in the phase of remission (an inactive phase of the disease).

As can be seen from our earlier work, a low level of antibodies is observed in the blood of healthy persons $(0.02 \mathrm{mg} / \mathrm{ml})$, in the blood of patients with chronic pancreatitis in the phase of remission $(0.11 \mathrm{mg} / \mathrm{ml})$, and in the blood of patients with cancer of pancreas (0.14). In the acute phase of chronic pancreatitis on the first days of the disease, the amount of antibodies was $0.19 \mathrm{mg} / \mathrm{ml}$, but it reached a rather high level in the 2nd-3rd week.

Electrofocusing has simplified the determination of the inflammatory processes of pancreas and cancer of pancreas. Fig. 2 gives isoelectric focusing of four different samples of human blood serum, where sample 1 was taken from a healthy person, sample 2 from a patient with the acute phase of chronic pancreatitis (2nd-3rd month), 3 from a patient with cancer of pancreas and 4 from a patient with acute pancreatitis (only 2 days of the disease).

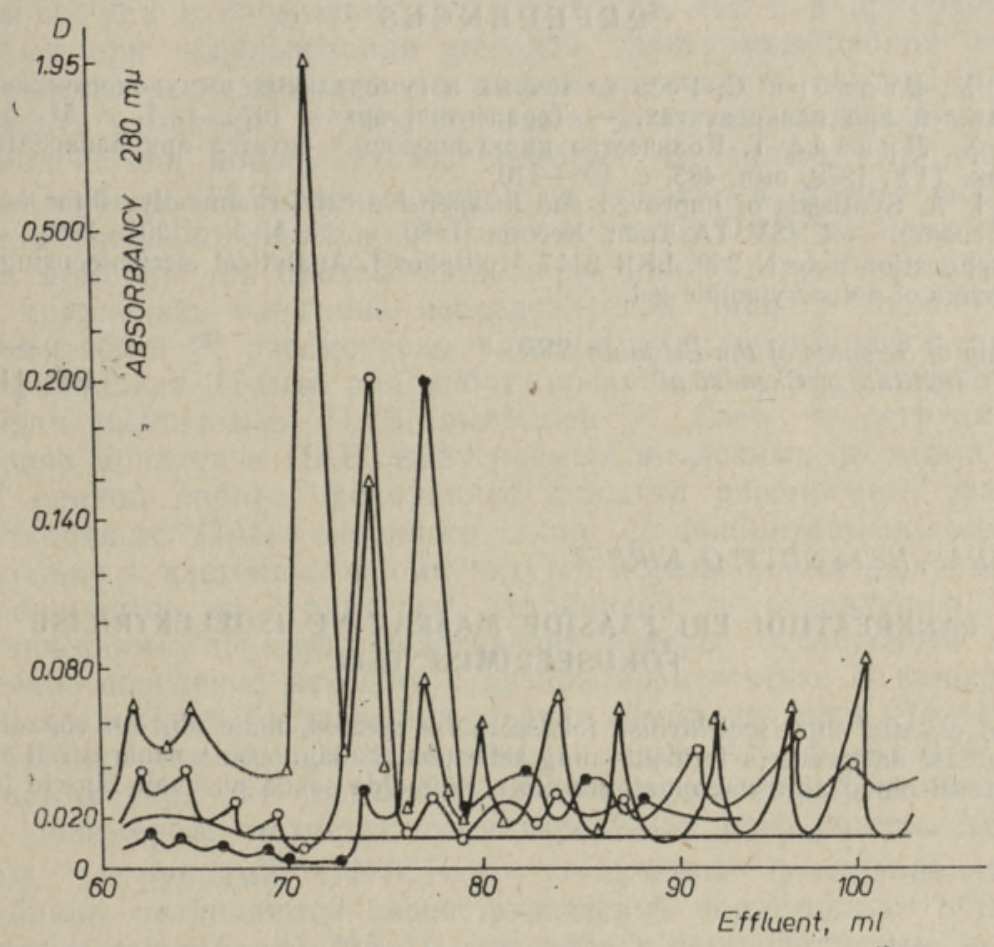

Fig. 4. Determination of antibodies against the tissue extract of pancreas and diagnostics of pancreatitis by affinity chromatography, using columns with a «Lahema» synthetic hydrogel Spheron P-1000, bound to a tissue extract of pancreas with 2-amino-4.6-dichlortriazine. The specific proteins were washed out with a physiological solution at $\mathrm{pH} 3.2$. 
As can be seen from the figure, in a normal adult, the pancreas gives a clear line pattern and there are strong major peaks between PI 5.9 and 6.8, and some other multiple faint peaks between PI 7.0 and 8.9 . Both chronic and acute pancreatitis give a peak at PI 5.5, but in case of chronic pancreatitis where the amount of antibodies has increased, a strong widening band emerges between PI 5.5 and PI 5.8. But in both cases strong clear peaks arise at PI 7.0 and 8.9 , but they are faint in case of healthy persons and those with cancer. In case of cancer of pancreas, a strong line arises at PI 5.1. Moreover, different blood groups give also different blood screening due to different proteins in the blood (Fig. 3), owing to which the blood screening of persons with similar diagnoses but different blood groups may differ.

In these experiments both donors and patients had blood group AB (IV).

Our experiments demonstrated that it is quite possible to diagnose pancreatitis, one of the most serious diseases in gastro-enterology, by using isoelectric focusing that is simple, more rapid and precise than affinity chromatography (Fig. 4).

It is clear that the problem requires further investigations.

\section{REFERENCES}

1. Нутт Х., Вель 6 ри С. Роль клеточных и гуморальных иммунологических показателей при панкреатитах. - Терапевтич. архив, 1970, т. 7, с. 51-54.

2. Нутт X., Линн а с Т. Количество циркулирующих антител при панкреатите. Уч. зап. ТГУ, 1979, вып. 485, с. $106-110$.

3. Murel, A. Synthesis of improved and inexpensive carrier ampholytes for isoelectric focusing. - ENSV TA Toim. Keemia, 1980, v. 29, N 3, p. 201-209.

4. LKB application note N 250, LKB 2117 Multiphor-1. Analytical electrofocusing in thin layers of polyacrylamide gel.

Academy of Sciences of the Estonian SSR, Institute of Chemistry

Received

Feb. 11, 1981

Tiina LINNAS, Helbe NUTT, O. KIRRET

\section{PANKREATIIDI ERI FAASIDE MAARAMINE ISOELEKTRILISE FOKUSEERIMISE TEEL}

Artiklis on esitatud uus isoelektrilise fokuseerimise meetod, mille abil on võimalik lähutada pankrease antigeene ja fermente ning selle põhjal diagnoosida pankreatiidi eri faase. Seni kasutusel olnud afiinsuskromatograafía ei vōimalda saada piisavalt täpseid tulemusi.

\section{ОПРЕДЕЛЕНИЕ РАЗЛИЧНЫХ ФАЗ ПАНКРЕАТИТА ПРИ ПОМОЩИ ИЗОЭЛЕКТРОФОКУСИРОВАНИЯ}

В статье рассмотрен новый метод изоэлектрофокусирования. Авторы пришли к выводу, что есть возможность разделять различные антигены и ферменты панкреаса и на этом основаннии диагностировать различные фазы панкреатита. 